Regards sur l'économie allemande

Bulletin économique du CIRAC

$118-119 \mid 2015$

Varia

\title{
Conte économique
}

BECK Hanno, SCHWOCH Juliane, Das Rätsel vom Fluss - Von leeren

Kornkammern, gefährlichen Geschäften und der Wasserratte, die baden ging

\section{Solène Hazouard}

\section{OpenEdition}

\section{Journals}

Édition électronique

URL : http://journals.openedition.org/rea/4914

DOI : $10.4000 /$ rea.4914

ISSN : 1965-0787

\section{Éditeur}

CIRAC

\section{Édition imprimée}

Date de publication : 31 décembre 2015

Pagination : 45

ISSN : 1156-8992

\section{Référence électronique}

Solène Hazouard, « Conte économique », Regards sur l'économie allemande [En ligne], 118-119|

décembre 2015, mis en ligne le 31 décembre 2015, consulté le 25 septembre 2020. URL : http:// journals.openedition.org/rea/4914 ; DOI : https://doi.org/10.4000/rea.4914

Ce document a été généré automatiquement le 25 septembre 2020.

(c) CIRAC 


\section{Conte économique}

BECK Hanno, SCHWOCH Juliane, Das Rätsel vom Fluss - Von leeren Kornkammern, gefährlichen Geschäften und der Wasserratte, die baden ging

Solène Hazouard

\section{RÉFÉRENCE}

BECK Hanno, SCHWOCH Juliane, Das Rätsel vom Fluss - Von leeren Kornkammern, gefährlichen Geschäften und der Wasserratte, die baden ging, Frankfurter Allgemeine Buch, Francfort-sur-le-Main, 2014, 134 p.

1 Un économiste et une historienne de l'art, tous deux journalistes, ont choisi de présenter l'économie sous la forme d'un livre de contes illustré, qui s'adresse aussi bien aux enfants qu'aux plus grands. Une manière ludique et accessible à tous d'explorer des notions comme la crise, l'épargne, l'endettement ou encore la division du travail. 